\title{
The Agricultural Land Conversion: Finding the Legal, Social and Economic Impacts
}

\author{
Agita Chici Rosdiana $^{\mathbf{l a}}$, Ghina Elmira $^{\mathbf{l b}}$, Ricky Adhitama M.P. ${ }^{\mathbf{1 c}}$ \\ ${ }^{1}$ Faculty of Law, Universitas Negeri Semarang (UNNES), Indonesia \\ a agitachici@gmail.com, ${ }^{\mathbf{b}}$ ixdghinaelmira@gmail.com, ${ }^{\mathbf{c}}$ rickyadhitama63@gmail.com
}

\begin{abstract}
The development of land needs in Indonesia is always increasing every year, this of course happens because of the various interests that require land as a primary need and in fact the land has a fixed nature with human population and the need for land is increasing, making land prices more expensive. The need for land conversion has resulted in a decrease in the availability of land around the Semarang area, especially in the village of Talun Kacang. Land conversion has several impacts, both positive and negative. One of the real impacts for the local community with this development is that the surrounding community feels benefited because the construction of this reservoir is able to revive tourism around the reservoir and of course that can bring in rupiah coffers which are said to be guaranteed by the welfare of the local community, especially the farmers who lost his land which also received appropriate compensation. Increased welfare of local village communities can be done by developing several economic and tourism sectors. This paper highlights that the existence of land conversion occurs, of course there is a great deal of social dynamics in the community, for this article examines the effects of the conversion of agricultural land to search for legal, social and economic impacts that occur in the community.
\end{abstract}

Keywords — land conversion; welfare; farmer.

\section{INTRODUCTION}

Semarang is a capital city of Central Java with an area of $373.70 \mathrm{Km}$ which this city has become one of the metropolitan city in Indonesia because of the many construction of skyscrapers have been found in Semarang city such as hospitality buildings, shopping centers, and other skyscrapers. Semarang has two terrestrial plains and lowlands, where the lowlands are narrow and about $4 \mathrm{~km}$ from the coastline or we call the lower cities where this lowland is very likely to become a subscription to disasters such as floods, such as problems that do not become public secret, that is the problem of floods often occur in this area, Semarang City government always plan and develop innovations so that floods and floods of rob in the city of Semarang can be overcome. While the highlands have evolved into the center of agglomeration of the population or the upper city, due to the cooler and fresher areas, the upper city area is widely developed into a natural tourist center in Semarang City because in this city is a green area for the government is not arbitrary in giving permit in the use of land in this city that in fact is a green field.

As mentioned in the above paragraph, Semarang City, which is a metropolitan city, is not only seen as a modern city, Semarang City certainly has some unavoidable problems. According [16] such as the big flood problem in Semarang city in 1973, 1988, 1990 and 1993. Floods in 1990 caused 47 deaths. Lack of raw water supply especially in the dry season that happens almost every year. This is exacerbated by the increasing population growth every year and environmental damage caused by humans or natural disasters. Decreased land due to excessive groundwater exploitation. Intrusion of seawater through rivers and waterways that occur almost every tide,
For that government to overcome the problem the government in cooperation with the Government of Japan held IWRMFP for Semarang dug IP Loan 534, one of which Jatibarang Reservoir construction.

According (Todaro, 2000: 17-18). Development is a multidimensional process which includes changes in social structure, changes in people's attitudes and changes in national institutions. In addition, development also includes changes in the level of economic growth, reducing national income inequality and eradicating poverty. In order to achieve the desired goals in development, the development of a country can be directed to three main things, namely, increasing the availability and distribution of basic needs for the community, improving the welfare of the community and increasing the ability of the community to access both economic activities and social activities in their lives.

The purpose of this research was to identify the impacts caused by the construction of the Jatibarang reservoir against the surrounding community. So that can be identified how much impact can be generated from the construction of this reservoir, especially in the structure of society which experienced a transition profession, and can be used as useful information and useful for all parties and all circles. From the description then comes a question "how to change the function of land according to UUPA with the existing reality and how the impact of land conversion to the livelihood of Talun Kacang villagers?"

\section{RESEARCH METHOD}

According [12] methodology is derived from the word "method" which means "way to" and is usually formulated in the presence of possibilities as a type of writing that can 
be used in research and research or a technique common to science or how to carry out a procedure. The basic technique of analysis is a tool to perform a process of analysis in research. In this case, the technical analysis used refers to qualitative research methods. Based on that, the method of discussion is done by using descriptive method, that is by collecting, analyzing, and summarizing data and information needed related to research problem.

Approach of research: The approach to the research is juridical and empirical legal research. According (Soemitro, 2007: 10) Juridical legal research is a legal research conducted by examining library materials or secondary data. While empirical law research is a problem approach on the things that are juridical and the reality that exists. Based on Law Number 5 Year 1960 on Basic Regulation of Agrarian Principles, Law No. 41 Year 2009 on Sustainable Land Farming Protection and Government Regulation No. 1 Year 2011 on Stipulation and Transfer of Land Use Sustainable Farming. According to the empirical approach of knowledge is based on facts obtained from the results of research and interviews. The research is based on the scientific method that is part of the empirical approach.

Type of research: The type of research is Qualitative research method. According [8] Qualitative research usually explains the images that have been obtained by knowing the meaning in the event by trying to interact with people in certain situations. Qualitative research makes the researchers seek meaning, understanding, understanding, verstehen, about a phenomenon, event, and human life by directly or indirectly involved. In the study, the researcher can not complete his research once, but through the stages so that the meaning can be concluded during the process from beginning to end activity, narrative and holistic.

The research process can be seen as a series of interrelated phases and cannot be separated from one another. The research work must have designed the framework in the steps of the research activity. At least there are three main stages in qualitative research that is (Sugiyono, 2007):

1. Description stage or orientation stage. At this stage, researchers begin to have images that have been seen, heard or perceived. In this stage, the researcher only cursory about the information obtained. In the description stages there are steps to identify a problem, a problem is something that can cause a question. As in this research, the researcher identify how the impact of land conversion to the livelihoods of Talun Kacang villagers in constitution?

2. Reduction stage. At this stage, all information that has been obtained by the researcher in the first phase begins to be reduced or reduced to focus on the core problem. So the second step, which is the problem or research focus, and the third step, namely the determination of research focus which means limiting a research. The essence of this stage is how important the usefulness of the research.

3. Selection stage. At this stage, the researcher sets out the established focus to be more detailed then conducts in- depth analysis of the focus of the problem. The result is a constructed theme based on data acquired into one knowledge, hypothesis, even new theory. In this step there are several steps, the fourth step is the stage of data collection which in this study, the primary data collection through field observation is done by direct observation and direct observation in the location area Jatibarang Reservoir area, questionnaires and interviews. Questionnaire, which provides questions in writing that are answered in writing also by respondents. While the interview, which held a question and answer directly to the respondents are the managers, farmers and farm workers, visitors and business owners who are located around Goa Kreo attractions and Jatibarang Multipurpose Reservoir. The secondary data, obtained from the observations that have been conducted and also has been selected which represents the problems and also of books, literature, scientific journals, and the applicable legislation and other written sources related to the problem under study . The fifth step, processing and meaningful data can be developed after the data in the fourth step has been collected. Next step six, the emergence of theory. And the seventh step, reporting the results of research, is a concrete result completeness of the research process with full responsibility by researchers.

\section{RESUlT AND DISCUSSION}

\section{A. Over Land Sustainable Functions}

The land is a gift of God Almighty to all mankind who stands on this earth. From birth to death, humans need land for shelter and land is the main source of life. Thus, the land is a basic need and God's grace for humans in meeting their basic needs. That way, the land can be used as a means to achieve the welfare of the nation. The idea has become the basis of constitutional mandate as included in article 33 paragraph (3) of the 1945 Constitution. In that article it reads like this: "The earth, water, and natural resources contained therein are controlled by the state and used for the greatest prosperity of the people. "The idea has a meaning which gives power to the state to regulate the natural resources contained within the territory of the Unitary State of the Republic of Indonesia in order to improve the lives of all Indonesian people.

The soil has a very important and vital meaning for human life. In addition, land is a treasure that can be said to be permanent because the land can be reserved for life in the future, unlike other goods such as vehicles or electronic devices that have high selling value when the goods are sold for the first time, and will decrease in price if the goods are considered ancient, because the age will always develop and the technology will be more sophisticated, while the land if someone bought it at this time and will sell it in the future, the price of land will always rise when sold because the land will be narrower.

Reference [11] stated that land is both social assets and capital assets when viewed from their functions. As a social asset, land is a means of binding social unity among the community for life and life. As a capital asset, land is a 
capital factor in development and has grown as a very important economic object as well as trading material and object of speculation. Land use change is a process of land use change from the original form of a particular use used to other needs such as land use is used as non-agricultural. Concerning to this, [12] stated that, defining land conversion or land conversion is a change of function in part or all of the area from the original function (as planned) to other functions that have negative impacts (problems) on the environment and the potential of the land itself. Aside from the above mentioned, the effect of land conversion can also affect the existing social structures in society, especially in influencing the livelihood structure of shifting communities. In the above statement as emphasized by [1], what is meant by conversion is the change of the old right to land into a new right to enact the Basic Agrarian Law. The conversion according to [2] is the adaptation of land rights that have been subject to the old legal system, namely land rights according to $\mathrm{BW}$ and lands that are subject to customary law to enter in the system of land rights under the provisions of UUPA. Meanwhile, according to expert [9], Conversion of land rights is a change of title to land in connection with the coming into effect of UUPA. The land rights that existed before the coming into effect of the UUPA were changed to land rights set forth in the UUPA (Article 16). Any rights to land existing before the UUPA apply, both western rights and Indonesian rights, by the provisions of UUPA conversion converted into one of the land rights referred to in the new land law.

The soil itself, according to [3] recognized as a part of the earth called the surface of the earth and on the surface of the earth is the human stand and defend life with a grounded board (land) as the primary needs. Land is one of the objects governed by agrarian law. The land regulated by the agrarian law is not land in its various aspects, but the land of its juridical aspect is directly related to the right to land which is part of the earth's surface as regulated in Article 4 paragraph (1) of the Basic Agrarian Law, : "On the basis of the right of control of the State as endorsed in article 2 it is prescribed the existence of various kinds of rights on the surface of the earth, which are called land which can be given to and possessed by persons either alone or together with other persons and bodies -legal entity."

\section{B. Analysis of Land Function Functioning in accordance with UUPA with Reality (The Legal Impacts)}

The transfer of the function of agricultural land in Talun Kacang village is based on the public interest, it is also regulated in article 44 paragraph 2 on the Protection of Sustainable Agriculture states that in the case of public interest, Sustainable Agriculture Farm as referred to in paragraph (1) can be converted, and implemented in accordance with the provisions of legislation. This is the factor that makes the agricultural land in Talun Kacang Village to switch function into reservoir, the function of this reservoir is aimed to reduce the flood that occurred in the city of Semarang. (4) "The transfer of Land function which has been stipulated as Sustainable Food Farm for the public interest as meant in sub-article (2) can only be done on condition, conducted strategic feasibility study".

Based on the results of our interviews on some key persons in the village, the local people did not admit that the land they converted was functioning as a reservoir, because they said that the land they used to have was less productive, besides the land they had at the time of maintenance cost is greater than the income received by the local farmers and it is this that makes the local people agree with the creation of this reservoir, with the community getting adequate compensation, this is in accordance with Article 18 Basic Agrarian Law no. 5 of 1960 which states "for the public interest, including the interests of the nation and the State and the common interest of the people, the rights to land may be repealed by compensating suitably and in a manner regulated by law." Compensation provided by the public is already through mediation process with local people, before agreement process about compensation had happened bargain between citizen with government, but in the end according to agreement that amount of compensation based on productivity of land, for productive land compensated Rp65.000 , - per meter whereas for unproductive soils are given compensation of half of the productive land per meter.

\section{The impact of the conversion of agricultural land to the farmers (The Social and Economic Impacts)}

The function of sustainable agriculture is the change in the function of sustainable agricultural land to non-sustainable agriculture land either permanently and temporarily. Environmentally sustainable development, according to [13] is the term sustainable development was first widely introduced by the World Commission on Environment and Development (WCED) in Common Future, which defines it as follows "Development that meets the needs of the present without compromising the ability of the future generation to meet their own needs."

According to Lestari, in defining land functions or commonly referred to as land conversion is a change in the function of some or all of the land area from its original function (as planned) to another function that can have a negative impact (problem) on the environment and the potential of the land itself . The impact of land use change also affects the social structure of the community, especially in the livelihood structure. It is true, as in our study, there was a shift in the social structure in the society especially in the social and economic fields of the community whose land was affected by the construction of reservoirs, the surrounding community with their considerations volunteered their land for reservoirs because the surrounding community thought there would be a positive impact in the future, expected like that. In the field of livelihood, the people who originally only worked as farm laborers (farmers), after the construction of this jatibarang multipurpose reservoir, made the surrounding community switch professions to become traders, tenants speet boats, open photo spots and the average citizen home became a home stay. It is said that there will be foreign 
tourists visiting the Jatibarang Reservoir and Kreo Cave, for that reason, the average household becomes a homestay and in front of their house has a bar that reads homestay.

In the research, researchers interviewed a farmer, young named Mr. Kasmi. According to the informant, the speaker agreed with the existence of this Jatibarang Multipurpose Dam Reservoir, even though the land was affected to become a reservoir, he agreed because of the compensation that has been in accordance with the agreement and it also change the profit instead of compensation, with the change of profit that people do not feel burdened and the absence of land dispute issues that complicate with the parties involved. This farmer or resource person does not feel disadvantaged because he thinks that if the land affected by the project is here the resource person buys the land in another area.

In this research, researchers interviewed a farmer named Mr. Kasmi. According to the informant, the resource person agreed with the construction of the Jatibarang Multipurpose Reservoir, even though the land was affected to be used as a reservoir, he agreed because of compensation in accordance with the agreement and according to him the compensation was not compensation, with the compensation that the community did not feel burdened and the absence of problems with land disputes that are complicated by the parties involved. This farmer or resource person does not feel aggrieved because he thinks that if the land affected by the project is here, the resource person buys land in another area, because indeed in the Gunungpati area is a cool and green area, there is still green land. So there are some green lands that accommodate. "Profitable because it made a reservoir to be crowded than before, the money is for necessity and can be made to buy more land." Said Mr. Karmi who until now still works as a farmer and spent the compensation money he made to buy land in another area to be able to continue his job as a farmer.

In addition, according to Ms. Soemar (82) the farmer and community elder leader stated that he was willing if the land was used for the construction of the reservoir, in the agreement there was a community agreement, in which residents asked not to enter outsiders before their citizens got work. In a sense, the local villagers must have a job by opening a trading business, leasing spead boats or opening photo spots or other trading businesses by utilizing the existing conditions, to be able to become an arena of creativity for the surrounding residents to develop the existing tourism village structure. That way the welfare of the surrounding community is quite guaranteed because of the construction of the reservoir with the bridge connecting Kreo Cave with the area of the residents' house and the photo spot where the bridge is predicted to be a landmark in the village and of course the development of the creativity of the village community who are in the village become a tourist village that can become a reflection of the surrounding tourism village.

\section{CONCLUSION}

The transfer of agricultural land in the village of Talun Kacang is based on the public interest, provided for in article 44, paragraph 2, on the Protection of Sustainable Agriculture states that in the case of the public interest, the Sustainable Agriculture Farm as referred to in paragraph (1) may be converted, the provisions of the legislation. This is the factor that makes the agricultural land in Talun Kacang Village to switch function into reservoir, the function of this reservoir is aimed to reduce the flood that occurred in the city of Semarang. Based on the results of our interviews with some key persons in the village, stated that the local people do not claim to object if the land they converted functioned to be a reservoir, because with this the people get a reasonable compensation, this is in accordance with Article 18 Basic Agrarian Law No. 5 of 1960 which states "for the public interest, including the interests of the nation and the State and the common interest of the people, the rights to land may be repealed by compensating suitably and in a manner regulated by law." Compensation provided by the public has been through the mediation process with local residents.

The transfer of sustainable agriculture forever does not only have a bad effect due to the impact of development for other common interests, in this case the authors conclude that with the transfer of sustainable agricultural land in Talun Kacang Village has made a shift in the community structure in the village. from the beginning the community around only have a profession as a farmer, after the construction of Jatibarang Reservoir, the community can reap the wisdom of the development, which, the surrounding community can open new stalls to trade, rent spead boat for the visitors who come, multitudinous, such as spot photographs above the air, snow and hot air balloon. The variety of creativity of the village youth cocks made his village grow into a tourist village.

\section{ACKNOWLEDGMENT}

Authors would like to express a great thankfulness to Ministry of Research and Higher Education, Republic Indonesia, especially Directorate General BELMAWA DIKTI, and Student Creativity Program Scheme. Thanks to: Rector of UNNES, Dean Faculty of Law UNNES, Mr Suhadi, and all lecturers on Faculty of Law UNNES, and all parties involved on this research.

\section{REFERENCES}

[1] Achmad, Ali Chomzah. 2004. Hukum Agraria (Pertanahan di Indonesia). Jakarta:Prestasi Pustakaraya.

[2] A.P.Parlindungan. Konversi Hak-hak Atas Tanah, Bandung: Mandar Maju, 1990.

[3] Arba. Hukum Agraria Indonesia, Jakarta: Sinar Grafika, 2015

[4] Dharma, Surya. Pendekatan, Jenis, dan Metode Penelitian Pendidikan, 2008 
[5] http://staff.uny.ac.id/sites/default/files/PENELITIA N\%20PENDIDIKAN.pdf accessed on 10 July 2018.

[6] Frisdiatara, Christea dan Imam Mukhlis. Ekonomi Pembangunan Sebuah Kajian Teoritis dan Empiris, Malang: Lembaga Penerbitan Universitas Kanjuruhan Malang, 2016

[7] I Made Mahadi Dwipradnyana. "Faktor-faktor yang Mempengaruhi Konversi Lahan Pertanian serta Dampak Terhadap Kesejahteraan Petani (Studi Kasus di Subak Jadi, Kecamatan Kediri, Tabanan)". Thesis, Universitas Udayana Denpasar, 2014.

[8] Muri, A. Yusuf. Metode Penelitian Kuantitatif, Kualitatif, dan Penelitian Gabungan, Jakarta: Kencana, 2014.

[9] Perangin, Effendi. Hukum Agraria di Indonesia Suatu Telaah dari Sudut Pandang Praktisi Hukum. Jakarta: Rajawali, 1990

[10] Prasetya, Dwi. "Dampak Alih Fungsi Lahan dari Sawah ke Tambak terhadap Mata Pencaharian Masayarakat Desa (studi kasus di Desa Cebolek Kidul Kecamatan Margoyoso Kabupaten Pati)", Thesis, Undergraduate Program Faculty of Law Universitas Negeri Semarang, Semarang, 2015,

[11] Rubaie, Achmad. Hukum Pengadaan Tanah Untuk Kepentingan Umum, Malang: Bayumedia, 2007.

[12] Soekanto, Soerjono. Pengantar Penelitian Hukum. Jakarta: UI Press, 1981.

[13] J. Iwan Azis, et.al. Pembangunan Berkelanjutan Peran dan Kontribusi Emil Salim. Jakarta: PT Gramedia, 2010.

[14] Undang-Undang No.5 Tahun 1960 tentang Peraturan Dasar Pokok-Pokok Agraria (UUPA)

[15] Undang-Undang No.41 Tahun 2009 tentang Perlindungan Lahan Pertanian Berkelanjutan.

[16] wikipemalijuana. 2018. Bendungan Jatibarang www.bbwspemalijuana.com accessed on 10 July 2018. 